\title{
Studies of Surfactant in Photogalvanic Cell for Solar Energy Conversion and Storage
}

\author{
Shiv Ram Saini, Shankar Lal Meena*, Ramesh Chand Meena \\ Department of Chemistry, JNVU, Jodhpur, India \\ Email: *slmeena.jnvu@gmail.com
}

How to cite this paper: Saini, S.R., Meena, S.L. and Meena, R.C. (2017) Studies of Surfactant in Photogalvanic Cell for Solar Energy Conversion and Storage. Advances in Chemical Engineering and Science, 7, 125-136.

https://doi.org/10.4236/aces.2017.72010

Received: November 18, 2016

Accepted: March 4, 2017

Published: March 7, 2017

Copyright $\odot 2017$ by authors and Scientific Research Publishing Inc. This work is licensed under the Creative Commons Attribution International License (CC BY 4.0).

http://creativecommons.org/licenses/by/4.0/

(c) () Open Access

\begin{abstract}
The photogalvanic effect was studied in photogalvanic cell containing orange $\mathrm{G}$ as Photosensitizer, sodium lauryl sulphate and EDTA as reducing agent. The photo-outputs with EDTA are higher for Solar Energy Conversion and Storage. The current-voltage relations of the cell have been measured in the dark and light under both forward and reverse direction. The photo potential and photocurrent generated was found to be $960.0 \mathrm{mV}$ and $350.0 \mu \mathrm{A}$, respectively. The observed conversion efficiency was $1.52 \%$ fill factor and the maximum power of cell was $0.47 \mu \mathrm{A}$ and $158.9 \mu \mathrm{W}$. The storage capacity of the cell was 80.0 minutes in dark. A mechanism was proposed for the generation of photocurrent in photo galvanic cell.
\end{abstract}

\section{Keywords}

Orange-G, NaLS (Surfactant), Photopotential, Photocurrent, Conversion Efficiency

\section{Introduction}

The worldwide demand for energy is expected to keep increasing at 5 percent each year [1]. Nowadays there are several major directions for solar technology development for photo galvanic that system directly converts the solar energy into electrical energy. Becquerel [2] first observed in 1839 the flow of current between two unsymmetrical illuminated metal electrodes in sunlight. Later, it was observed by Rideal [3] and Rabinowitch [4]. A dye sensitized solar cell (gratzed cell) which is based on a semiconductor formed between a photosensitized anode and on electrolyte systematic investigation was done [5]. And a metal based photo galvanic solar panel is the most commonly used solar technology 
to generate electrical energy was studied [6]. Use of some reductant and photo sensitizer in photo galvanic cells for solar energy conversion and storage was investigated [7]. The studies of photo galvanic cell consisting various dyes with reductant and surfactant were done [8] [9]. Recently the photo galvanic effect in various interesting system were observed [10] [11]. The photo chemical conversion of solar energy into electrical energy was studied [12] [13].

A detailed literature [14]-[20] survey reveals that different photosensitize and EDTA have been used in photo galvanic cells, but no attention has been paid tousle of the NaLS-orange G system in the photo galvanic cell for solar energy conversion and storage.

\section{Experimental \& Materials}

The system contains orange G dye NaLS (surfactant), EDTA and water, used in the reported system is distilled twice in the laboratory only. All the Solutions were prepared in doubly distilled water and kept in amber colored containers to protect them from sunlight. A mixture of solution of NaLS, (Sodium Lauryl Sulfate) orange G, EDTA and sodium hydroxide was taken in an $\mathrm{n} \mathrm{H}$-shaped glass tube. A platinum electrode $\left(1.0 \times 1.0 \mathrm{~cm}^{2}\right)$ was immersed into one arm of the $\mathrm{H}$-tube and a saturated calomel electrode (SCE) was kept in the others, the whole system was first placed in dark till a stable potential was obtained and then, the arm containing the SCE was kept in the dark and the platinum electrode was exposed to a 200 tungsten lamp. A water filter was used to cut off infrared radiations. The photochemical bleaching of orange $G$ was studied potentiometrically. A digital $\mathrm{pH}$ meter (modal-III) and a microameter were used to measure the potential and current generated by the system, respectively. The experimental set-up of photogalvanic cell is given in Figure 1.

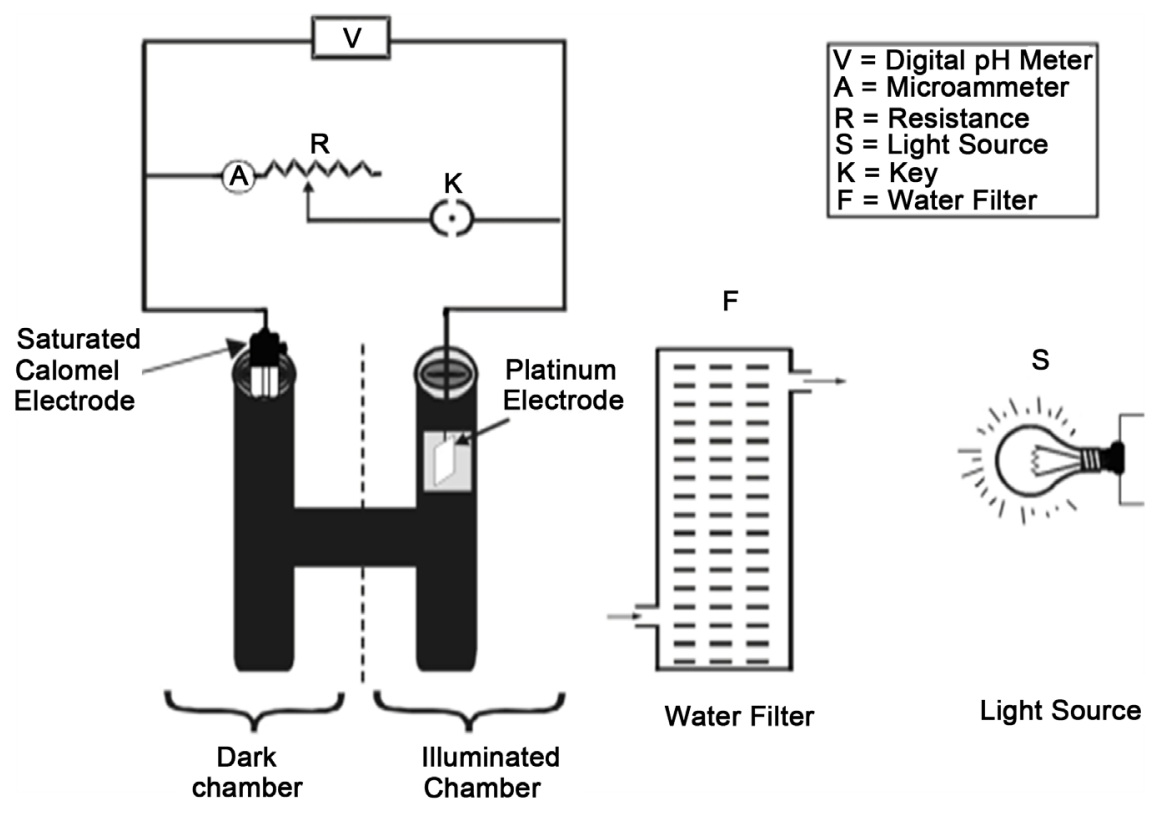

Figure 1. Experimental set-up of photo galvanic cell. 
<smiles>O=[N+]([O-])c1cc(S(=O)(=O)[O-])cc2ccc(O)c(/N=N/c3ccccc3)c12</smiles><smiles>CCCCCCCCCCCCOS(=O)(=O)O[Na]</smiles>
Orange GNaLS (Sodium Lauryl Sulfate)<smiles>O=C(O)CN(CCN(CC(=O)O)CC(=O)O)CC(=O)O</smiles>

EDTA

\section{Result and Discussion}

\subsection{Effect of Variation of Surfactant [NaLS] Concentration}

The photo galvanic cell having orange G-EDTA-NaLS system, the photo potential and photocurrent were increased with the increase in concentration of the surfactant. A maximum was found for a particular value of NaLS concentration, above which decrease in electrical output of photo galvanic cell was obtained. All observed results are reported in Figure 2. The reason of the change in electrical output is that micelles solublize the dye molecules up to highest extend at or around their micelles concentration upon increase in NaLS concentration to a value higher than CMC a charge transfer complex between dye and surfactant which is hydrophobic in nature so a fall in electrical output was observed.

\subsection{Effect of Variation of Reductant Concentration}

The electrical outputs of these electrochemical cells were found to increase with the increase in the concentration of the reducing agent till it reaches an optimum value. Then there was a decrease in photo potential and photo current both on further increase in the concentration of the reductant. The fall in the concentration of reductant also resulted into fall in power output due to less number of molecules available for electron donation to the cationic form of the dyes .On the other hand, higher concentration of the reductant will hinder the movement of dyes molecules to reach, the electrode in the desired time limit. The observed result are given in Figure 3.

\subsection{Effect of Variation of Photo Sensitizer (Dyes) Concentration}

The effect of variation of photosensitizer (dyes) concentration has been studied. It was observed that there was an increase in photopotential and photocurrent on increasing the concentration of photosensitizer. It was felt necessary to keep the concentration of photosensitizer (dyes) for effective results in electrical output. On the lower side of concentration range of photosensitizer, there will be 


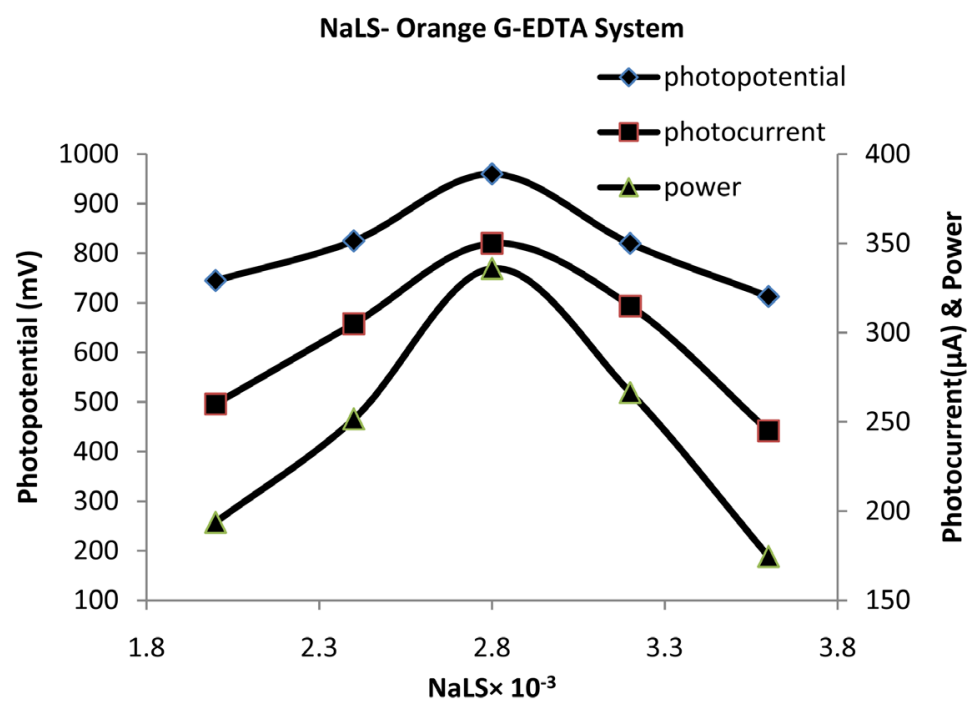

Figure 2. Variation of photopotential, photocurrent and power with NaLS concentration.

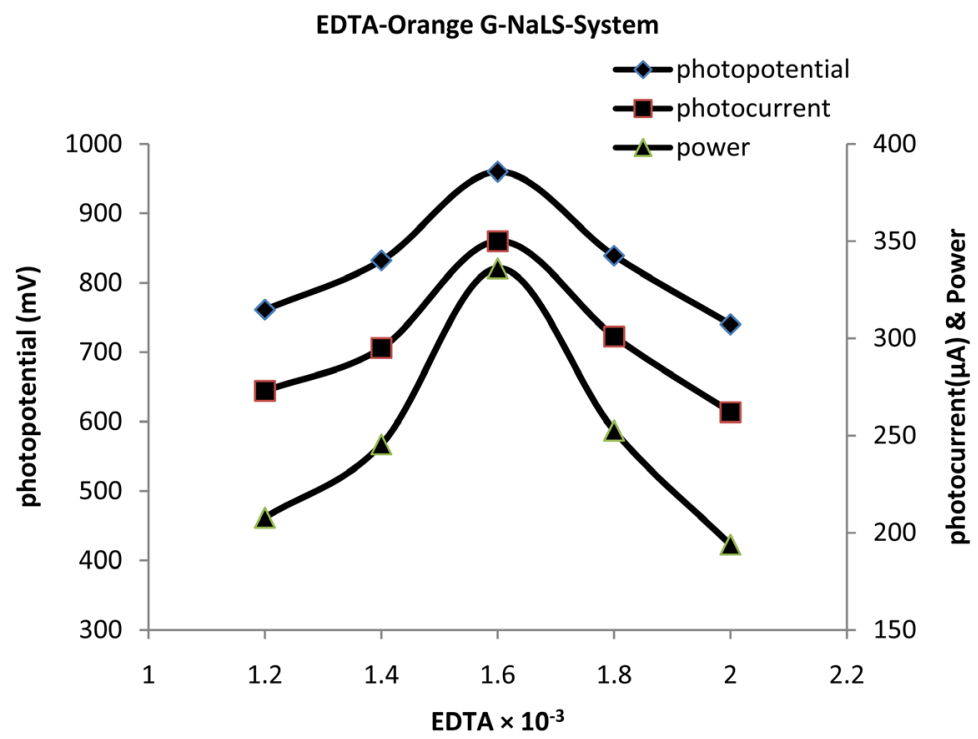

Figure 3. Variation of photopotential, photocurrent and power with EDTA concentration.

limited number of photosensitizer molecule to absorb the solar light in cell and, therefore, there is low electrical output whereas higher concentrations of photo sensitizer will not permit the desired light intensity to reach the photosensitizer molecules near the electrodes and hence, there will be a corresponding fall in the power of the cell.

1. On the iower concentration range of orange $G$, there is a limited number of photosensitized molecules to absorb the major portion of the light and therefore, a few number of electrons can reach the platinum electrode and a low electrical output was obtained;

2. Higher concentration of the dye does not permit the desired light intensity to reach the molecules near the electrodes and hence, there is a corresponding fall in the power of the cell; 
3. Due to the high concentration, there are short lived excited dye states therefore; an excited dye molecule must reach $\mathrm{Pt}$ within its short life for electron donation. Give these, only dye molecules that exist and absorb photons near $\mathrm{Pt}$ have greater chance of electron donation to Pt electrode;

4. The increased concentration of dye under operational conditions may also lead to be accelerated recombination between the injected electrons and dye accompanied by losses of photocurrent and photovoltage and reduced conversion efficiencies.

The effects of variation of photosensitizer are reported in Figure 4.

\subsection{Effect of PH}

The electrical output of the cell was affected by the variation in $\mathrm{pH}$ of the system. That there is an increase in electrical output of the cell with the increase in $\mathrm{pH}$ values. At $\mathrm{pH} 12.8$ a maxima was obtained. Further increase in $\mathrm{pH}$, a decrease in photo potential and photocurrent was observed. Thus, photo galvanic cell containing the orange G-EDTA and NaLS system were found to be quite sensitive to the $\mathrm{pH}$ of the solution. The effect of variation of $\mathrm{PH}$ on photo potential and photocurrent are given in Figure 5.

\subsection{Effect of Diffusion Length}

Conversion of solar energy into electrical energy of the cell is also affected by the diffusion length of the cell. With the increase in the diffusion length the current also increases. Maximum current of the cell is observed to increase first with increase in diffusion length and then decrease on further increase in the diffusion length whereas equilibrium current $i_{e q}$ and rate of generation of current are found to increase slightly. The results are shown as below in Table 1.

orange G-NaLS-EDTA system

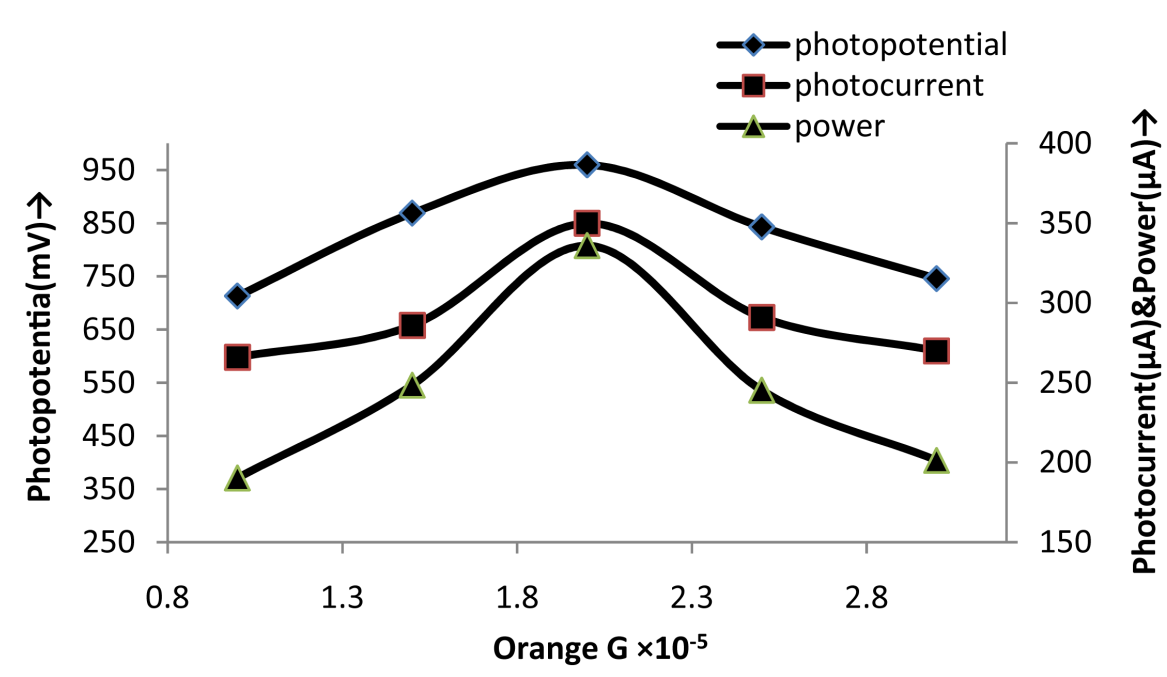

Figure 4. Variation of photopotential, photocurrent and power with orange g concentration. 


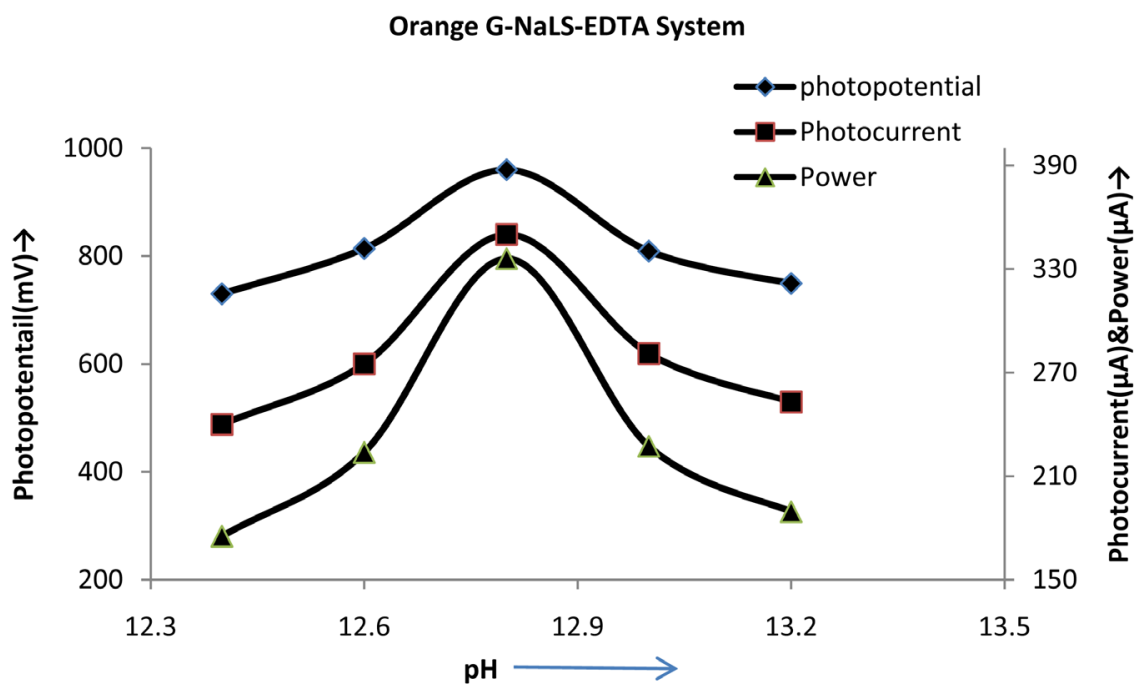

Figure 5. Variation of photopotential, photocurrent and power with $\mathrm{pH}$.

Table 1. Effect of diffusion length.

\begin{tabular}{cccc}
\hline \multicolumn{5}{c}{$\begin{array}{c}\text { Orange G }+ \text { EDTA }+ \text { NaLS System } \\
\text { Orange G }=5.9 \times 10^{-5} \mathrm{pH}=12.8 \\
\text { Temp. }=303 \mathrm{~K} \text { Light intensity }=10.4 \mathrm{~mW} \cdot \mathrm{cm}^{-2} \\
\mathrm{EDTA}=2.2 \times 10^{-3} \mathrm{NaLS}=1.4 \times 10^{-3}\end{array}$} \\
\hline $\begin{array}{c}\text { Diffusion path } \\
\text { length } \mathrm{D}_{\mathrm{L}}(\mathrm{mm})\end{array}$ & $\begin{array}{c}\text { Maximum } \\
\text { photocurrent } \\
\mathrm{I}_{\max }(\mu \mathrm{A})\end{array}$ & $\begin{array}{c}\text { Equivalent } \\
\text { photocurrent } \\
\text { Ieq }(\mu \mathrm{A})\end{array}$ & $\begin{array}{c}\text { Rate of initial } \\
\text { generation of current } \\
\left(\mu \mathrm{A} \cdot \mathrm{Min}^{-1}\right)\end{array}$ \\
\hline 35.0 & 280 & 240 & 12.55 \\
40.0 & 304 & 276 & 14.87 \\
45.0 & 385 & 350 & 20.99 \\
50.0 & 320 & 290 & 19.50 \\
55.0 & 270 & 255 & 16.90 \\
\hline
\end{tabular}

\subsection{Light Intensity and Temperature}

Photo galvanic effect is a light induced phenomenon and depends upon the intensity of light. Intensity of light increases photo potential and photocurrent both increases. Tungsten bulbs of various watts were used to vary light intensity and the result is as tabulated in Table 2.

\subsection{Effect of Electrode Area}

The effect of electrode area on the current parameters of the cell has also been studied. It was observed that with the increase in the electrode area the value of photopotential is found to increase. All observed results with respect to effect of electrode area are summarized in Table 3.

\section{Performance of the Cell and Conversion Efficiency}

The open-circuit voltage $\left(V_{o c}\right)$ and short-circuit current $\left(i_{s c}\right)$ of the photo galvanic cell were measured by means of a digital multimeter (keeping the cir- 
Table 2. Effect of Light intensity and temperature.

\begin{tabular}{cccc}
\hline \multicolumn{4}{c}{$\begin{array}{c}\text { Orange } \mathrm{G}+\mathrm{EDTA}+\mathrm{NaLS} \text { System } \\
\text { Orange } \mathrm{G}=5.9 \times 10^{-5} \mathrm{pH}=12.8 \\
\text { Temp. }=303 \mathrm{~K} \text { Light intensity }=10.4 \mathrm{~mW} \cdot \mathrm{cm}^{-2} \\
\mathrm{EDTA}=2.2 \times 10^{-3} \mathrm{NaLS}=1.4 \times 10^{-3}\end{array}$} \\
\hline $\begin{array}{c}\text { Intensity of } \\
\text { Light } \mathrm{mW} \cdot \mathrm{cm}^{-2}\end{array}$ & $\begin{array}{c}\text { Photo } \\
\text { Potential }(\mathrm{mV})\end{array}$ & $\begin{array}{c}\text { Photo } \\
\text { Current }(\mu \mathrm{A})\end{array}$ & Log V \\
\hline 3.1 & 892 & 265 & 2.37 \\
5.2 & 918 & 280 & 2.41 \\
10.4 & 960 & 350 & 2.52 \\
15.6 & 980 & 385 & 2.57 \\
26.0 & 998 & 390 & 2.59 \\
\hline
\end{tabular}

Table 3. Effect of electrode area.

\begin{tabular}{ccc}
\hline \multicolumn{3}{c}{ Orange G + EDTA $+\mathrm{NaLS}$ System } \\
Orange G $=5.9 \times 10^{-5} \mathrm{pH}=12.8$ \\
Temp. $=303 \mathrm{~K}$ Light intensity $=10.4 \mathrm{~mW} \cdot \mathrm{cm}^{-2}$ \\
EDTA $=2.2 \times 10^{-3} \mathrm{NaLS}=1.4 \times 10^{-3}$
\end{tabular}

cuit closed). The current and potential between two extreme values $\left(V_{o c}\right)$ and $\left(i_{s c}\right)$ were recorded with the assistance of a carbon pot (linear $470 \mathrm{~K}$ ) that was connected in the circuit of the multimeter and through which an external load was applied. The $\mathrm{i}-\mathrm{V}$ characteristics of the cell containing Orange G EDTANaLS System are shown graphically in Figure 6. And cell performance in Figure 7.

Rectangular shape. A point in the $\mathrm{i}-\mathrm{V}$ curve, called the power point (pp), was determined where the product of photocurrent and photo potential is maximum. The potential and the current at the power point are represented by $\left(V_{p p}\right)$ and $\left(i_{p p}\right)$ respectively. With the help of the (i-V) curve, the Fill Factor and Conversion Efficiency of the cell are found to be $0.47 \%$ and $1.52 \%$ respectively, using the formulae.

$$
\begin{gathered}
\text { Fill Factor }=\frac{V_{p p} \times i_{p p}}{V_{o c} \times i_{s c}} \\
\text { Conversion Efficiency }=\frac{V_{p p} \times i_{p p}}{10.4 \mathrm{~mW} \cdot \mathrm{cm}^{-2}} \times 100 \%
\end{gathered}
$$

$10.4 \mathrm{~mW} \cdot \mathrm{cm}^{-2}$ Artificial Illumination intensity.

The performance of the cell was studied by applying the external load that was 


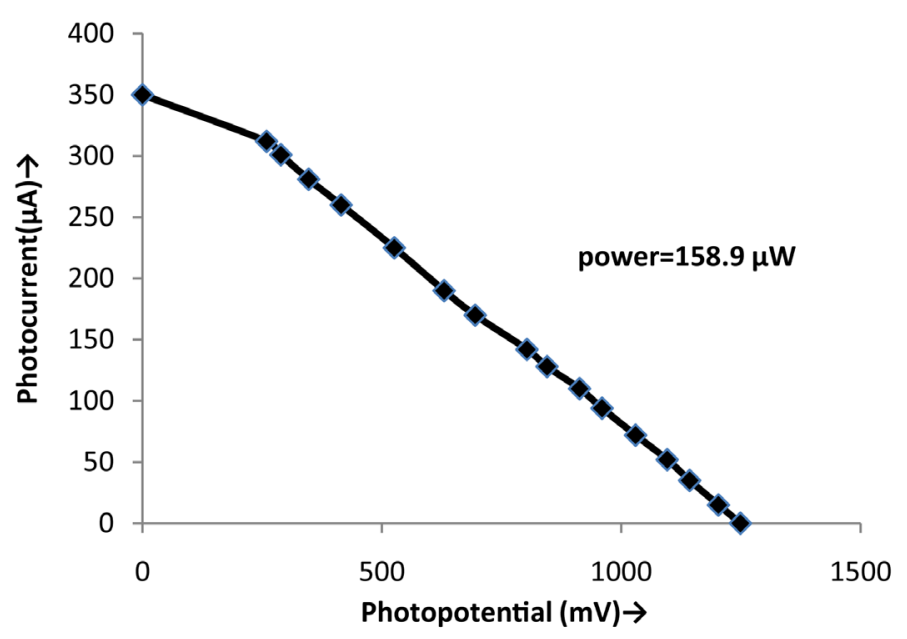

Figure 6. Current-voltage (i-v) curve of the cell.

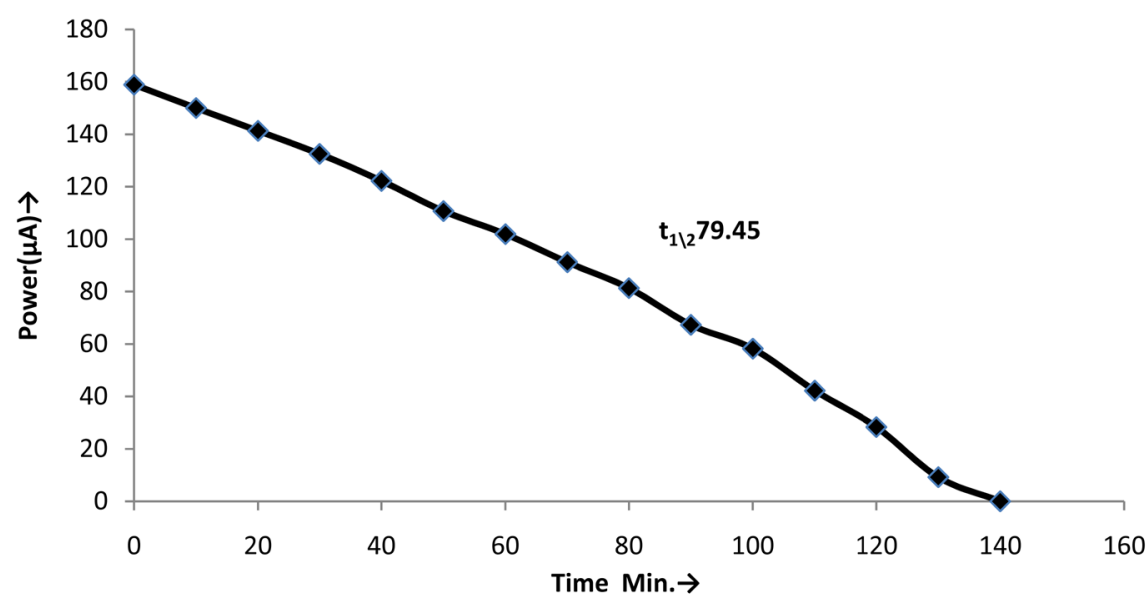

Figure 7. Performance of the cell.

necessary to have the current and the potential at the power point after removing the source of light. The cell can be used in the dark at its power point for $80.0 \mathrm{~min}$. Thus, whereas photovoltaic cell cannot be used in the dark even for a second, a photo galvanic system has the advantage of being used in the dark, but at lower conversion efficiency.

\section{Role of Surfactant}

The utility of surfactants in photogalvanic cells with respect to their nature has been investigated and found to follow the order anionic surfactants, neutral surfactants and cationic surfactants. Alkalis et al. have studied the photo ejection of electrons from dye-surfactant systems, suggesting the tunneling photoelectrons from the surfactants phase to the aqueous phase, whereas Mukhopadhaya and Bhowmik [21] have suggested the probability of some charge transfer between surfactant and dye. The used NaLS solubilise the dye more easily and stabilizes the system and may increase the probability of charge transfer between surfactant and the dye in the system. 


\section{Mechanism}

As no reaction is observed between the orange G and EDTA in the dark, it may be concluded that the redox potential of EDTA is much higher than that of Orange G. A rapid fall in potential is observed when the platinum electrode is illuminated. The potential reaches a steady value after certain period of exposure. Although the direction the change of potential does not returns to its initial value. This means that the main reversible photochemical reaction is also accompanied by some side irreversible reactions. The electro active species in this photo galvanic system is thus different from that of the well-studied Orange G-EDTA system. In the present case, the lecuo- or semi-reduced dye is considered to be the electrode active species in the illuminated chamber, and the dye itself in dark chamber.

On the basis of the above investigations the mechanism of the photocurrent generation in the photogalvanic cell can be proposed as follows.

\section{Illuminated chamber}

Bulk solution

$\mathrm{h} v$

Orange $\mathrm{G} \rightarrow$ Orange $\mathrm{G}-\mathrm{B}^{\star}$, (1)

Orange G-B ${ }^{\star}+\mathrm{R} \rightarrow$ Orange G-B- + R +, (2)

At electrode

Orange G-B- $\rightarrow$ Orange $\mathrm{G}-\mathrm{B}+e^{-}$, (3)

Dark chamber

At electrode

Orange G-B $+e-\rightarrow$ Orange G-B- (4) Bulk solution

Orange $\mathrm{G}-\mathrm{B}-\mathrm{R}+\rightarrow$ Orange $\mathrm{G}-\mathrm{B}$

Where $\mathrm{B}+\mathrm{B}^{-}, \mathrm{R}$ and $\mathrm{R}^{+}$are Orange $\mathrm{G}$, its semi or leuco form, reductant and it oxidized form, respectively.

\section{Conclusion}

On the basis of above results, it is concluded that orange G can be used successfully as photosensitizer in a photogalvanic cell. The conversion efficiency of the cell is $1.52 \%$ and the cell can be used in dark at its power point for $80.0 \mathrm{~min}$. Photogalvanic cells have the added advantage of having in-built storage capacity. The time is not far off when the conversion efficiency of these cells will be comparable with that of existing solar cells. Thus, photo galvanic cells show good prospects of becoming commercially viable.

\section{Acknowledgements}

Authors are grateful to the Head of the Department of chemistry, Jai Narian Vyas University, Jodhpur, for facilities and C.S.I.R. New Delhi, For Financial assistance to conduct this research work.

\section{References}

[1] Enerdata Global Energy Intelligence, World Energy Use in (2010) Over 5\% Growth 
May 2011.

[2] Becquerel, E. (1839) On Electrod Effect under the Influence of Solar Radiation. C.R. Acad. Sci., Paris, 9, 561.

[3] Rideal, E.K. and Williams. D.C. (1925) XLIII.-The Action of Light on the Ferrous Ferric Iodine Iodide Equilibrium. Journal of the Chemical Society, Transactions, 127, 258-269.

[4] Rabinowitch, E. (1940) The Photogalvanic Effect II. The Photogalvanic Properties of the Thionine-Iron System. Journal of Chemical Sciences, 8, 560-556.

[5] Kong, F.-T., Dai, S.-Y. and Wang, K.-J. (2007) Review of Recent Progress in Dye-Sensitized Solar Cells. Advances in OptoElectronics, 2007, Article ID: 75384.

[6] Ameta, S.C., Khamesra, S., Chittora, A.K. and Gangotri, K.M. (1989) Use of Sodium Lauryl Sulphate in a Photogalvanic Cell for Solar Energy Conversion and Storage: Methylene Blue-Edta System. International Journal of Energy Research, 13, 643 647. https://doi.org/10.1002/er.4440130604

[7] Gangotri, K.M. and Lal, C. (2000) Studies in Photogalvanic Effect and Mixed Dyes System: EDTA-Methylene Blue + Toluidine Blue System. International Journal of Energy Research, 24, 365-371.

[8] Gangotri, K.M. and Meena, R.C. (2001) Use of Reductant and Photosensitizer in Photogalvanic Cells for Solar Energy Conversion and Storage: Oxalic Acid-Methylene Blue System. Journal of Photochemistry and Photobiology A Chemistry, 141, 175-177.

[9] Madhwani, S., Ameta, R., Vardia, J., Punjabi, P.B. and Sharma, V.K. (2007) Use of Fluoroscein-EDTA System in Photogalvanic Cell for Solar Energy Conversion. Energy Source Part. A, 29, 721-729.

[10] Gangotri, K.M. and Bhimwal, M.K. (2010) The Photochemical Conversion of Solar Energy into Electrical Energy: Eosin-Arabinose System. International Journal of Electrical Power \& Energy Systems, 1106-1110.

[11] Bhatia, K.M. and Gangotri, K.M. (2011) Photogalvanic Conversion of Solar Energy into Electrical Energy by Using NaLS-Xylose-Methylene Blue System. International Journal of Electrical Power \& Energy Systems, 33, 155-158.

https://doi.org/10.1016/j.ijepes.2010.08.001

[12] Gangotri, K.M. and Meena, R.C. (1999) Use of Micelles in Photogalvanic Cells for Solar Energy Conversion and Storage: Cetyl Trimethyl Ammonium BromideGlucose-Toluidine Blue System. Journal of Photochemistry and Photobiology A: Chemistry, 123, 93-97. https://doi.org/10.1016/S1010-6030(99)00034-9

[13] Singh, A. and Meena, R.C. (2013) Role of Rose Bengal-Mannitol System for Generation of Electrical Energy in Photogalvanic Cell. International Journal of Physical Sciences, 7, 5642-5647.

[14] Chandra, M. and Meena, R.C. (2010) Role of Ponceau-S-Mannitol System for Generation of Electrical Energy in Photogalvanic Cell. Journal of Nepal Chemical Society, 26, 46-52. https://doi.org/10.3126/jncs.v26i0.3631

[15] Meena, R.C., Singh, G., Tyagi, N. and Kumari, M. (2004) Studies of Surfactants in Photogalvanic Cells-NaLS-EDTA and Azur-B System. Journal of Chemical Sciences, 116, 179-184. https://doi.org/10.1007/BF02708223

[16] Sindal, R.S., Gunsaria, P.K., Chandra, M. and Meena, R.C. (2006) Arabian Journal for Science and Engineering, 31, 177-184.

[17] Sirvi, S., Meena, V.K. and Meena, R.C. (2008) Studies on the Photochemical Interaction of Fuchsin Basic Dye with Triton X-100. Journal-Indian Chemical Society, 
$85,825-829$

[18] Sindal, R.S., Chandra, M. and Meena, R.C. (2008) Role of Rose Bengal as Photosensitizer for Solar Energy Conversion and Storage in Rose Bengal-Potassium Iodide System. Journal of the Indian Council of Chemists, 25, 131-136.

[19] Ameta, S.C., Khamesra, S., Bala, M. and Gangotri, K.M. (1990) Use of Micelles in Photogalvanic Cell for Solar Energy Conversion and Storage. The Philippine Journal of Science, 119, 371-373.

[20] Saini, S.R., Meena, S.B. and Meena, R.C. (2015) Studies of Surfactant and Photosensitizer in Photogalvanic Cell for Solar Energy Conversion and Storage: Methyl Violet NaLS and EDTA System. International Journal of Advanced Engineering Research and Technology, 3, 11-20.

[21] Mukhopadhyal, M. and Bhowmic, B. (1992) Kinetic of Photoinduced Electron Transfer in a Photoelectrochemical Cell Consisting of Thiiazine Dyes and Triton X-100 Surfactant. Photochemistry and photobiology, 62, 223-227. 


\section{Nomenclature}

$I_{e g}=$ photocurrent at equilibrium

$i_{\max }=$ maximum photocurrent

$i_{p p}=$ photocurrent at power point

$i_{s c}=$ short circuit current

$\mathrm{mv}=$ millivolt

$\mathrm{m}=$ molarity

$\mathrm{pp}=$ power point

$\mathrm{t}_{112}=$ storage capacity of cell

Dv $=$ observed photopotential

$\mathrm{Ocv}=$ open circuit voltage

$\mathrm{Vpp}=$ photopotential at the power point

$\mathrm{n}=$ fill factor

$\mathrm{mA}=$ microampere

$\mathrm{mW}=$ microwatt

\section{S.N Parameter Observed value}

1. Dark potential $289 \mathrm{mV}$

2. Open circuit voltage $1249 \mathrm{mV}$

3. Photopential (Dv) $960 \mathrm{mV}$

4. Equilibrium photocurrent $350 \mu \mathrm{A}$

5. Maximum photocurrent $385 \mu \mathrm{A}$

6. IGP $25.5 \mathrm{MA} \mathrm{min}^{-1}$

7. Times of illumination $130.0 \mathrm{~min}$

8. Storage capacity $\left(t_{112}\right) \quad 80.0 \mathrm{~min}$

9. $\%$ of storage capacity $57.14 \%$

10. Conversation efficiency $1.52 \%$
11.
Fill Factor (n)
$0.47 \mu \mathrm{A}$

Submit or recommend next manuscript to SCIRP and we will provide best service for you:

Accepting pre-submission inquiries through Email, Facebook, LinkedIn, Twitter, etc. A wide selection of journals (inclusive of 9 subjects, more than 200 journals)

Providing 24-hour high-quality service

User-friendly online submission system

Fair and swift peer-review system

Efficient typesetting and proofreading procedure

Display of the result of downloads and visits, as well as the number of cited articles

Maximum dissemination of your research work

Submit your manuscript at: http://papersubmission.scirp.org/

Or contact aces@scirp.org 